\title{
The Effect of a Pictorial Story-Based Instructional Writing Program on Enhancing the English Writing Performance of Jordanian Secondary Students
}

\author{
Nisreen Juma'a Al-Mashaqba \\ Qassim University, Methnab, Saudi Arabia
}

\author{
Fawwaz Al-Abed Al-Haq \\ Yarmouk University, Irbid, Jordan
}

\begin{abstract}
The purpose of this study was to investigate the effect of a pictorial story-based instructional writing program on enhancing the English writing performance of Jordanian secondary students. The participants of the study were 168 eleventh scientific grade students in two secondary schools, one male school and one female school that belong to Mafraq Directorate of Education. For the purpose of the study, the researcher designed a Pictorial Story-Based Instructional Program. A pretest was distributed to the students at the beginning of the experiment which started at the beginning of the first semester of the academic year 2012/2013 and lasted for 12 weeks; at the end of the program the posttest was administered. The results of the study showed that the Pictorial Story-Based Instructional Program developed the students' abilities in writing English short stories. The results also revealed that the students who used the program were motivated and their performance was influenced positively.
\end{abstract}

Keywords: pictorial story, pictorial story-based writing, writing performance

\section{Introduction}

Writing in the foreign language assumes a very important place as a means of communication. It is considered an important skill because it helps learners develop their thinking by allowing them to revisit their thoughts. In this regard, Brown (1987) believes that the communicative approach considers writing a conscious activity that requires mental effort in order to produce something meaningful and communicative. Conley (1995) believes that writing makes one's thoughts and experiences vivid and long lasting and it helps in learning things in every subject area. In many ways, writing is the way a sense of the world is made.

Students are weak in the writing skill, and they need to enhance their writing performance. They face difficulty in composing as they are required to produce good ideas arranged logically, using active vocabulary items and structures including discourse markers. This difficulty lies on how to produce meaningful sentences which comprise coherent text (Al-Abed Al-Haq \& Al-Sobh, 2012). Teachers concentrate on structure rather than the writing process and the current technique they use is not effective (Toubat, 2003; Batayneh, 1986; AL-Quran, 2002). Al-khresheh (2010) states, "in spite of the long period where English was taught in Jordanian schools and

Nisreen Juma'a Al-Mashaqba, assistant professor, Ph.D., Department of English and Translation, Qassim University. Fawwaz Al-Abed Al-Haq, professor, Ph.D., Department of English and Literature, Yarmouk University. 
the importance given to its curriculum, it is generally observed that students are unable to write a simple meaningful sentence without committing an error" (p. 105). Many Jordanian researchers found that Jordanian curricula still use the deductive approach in teaching grammar rules and writing (El-Mustafa, 1988; Saleh, 1990; Karsou, 2005; AI-Hishoush, 2006). As a result, Jordanian English curricula cannot stimulate the learners' thinking abilities and the lack of proficiency in writing is still a serious problem. Accordingly, it seems that there is a need to adopt new techniques of teaching writing that develop their abilities to be competent writers. Al-Bataineh (2010) believes that the weakness of writing skill might be due to the failure of the traditional methods of teaching in helping students and the teacher to learn/teach this skill efficiently. Al-Abed Al-Haq and Al-Sobh (2012) believe that there are many reasons for students' weakness in the writing skill, the most important of which is the technique of teaching. Moreover, they think that there is a need to adopt new techniques for teaching writing that may help students be better writers. The teaching aids may positively affect students' writing.

Because of the strong relationship between writing and thinking and because of the evident role of writing in enhancing thinking, educators emphasize the importance of teaching thinking skills in order to help students be better thinkers (Bear, 1988; Cotton, 1997; Morgan \& Forster, 1999; Newton, 2000; Oslon, 1984; Presseisen 1988). That is why many researchers emphasized the importance of supporting students with enough writing tasks in order to enhance their thinking abilities (Bland \& Koppel, 1988; Calkins, 1994; Garvie, 1990; Howe, 1996).

Carter, Holland, Mladic, Sarbiewski, and Sebastian (1998) explained the role of pictures in enhancing the students' ability to create creative stories by saying that the absence of words helps the reader create his own story by the picture he sees rather than the words he reads. As a result, it is likely that there is an evident need for using wordless picture books in order to provide students with the suitable environment to produce original creative writings.

Henry (2003) explained the role of wordless picture books in stimulating students' creativity by saying that the creativity stimulated by wordless picture books encourages older students to look more closely at story details, to consider all story elements and to understand how to organize the learners' text so that a story develops. Henry found that students who used wordless picture books were able to build their reading and writing skills and strategies to ultimately produce a unique book.

Pictorial stories can stimulate students' thinking. However, students are not encouraged to write these stories and the lack of creativity is obvious in their writing (Ellis, 2003; Schneider, 2006). As a result, students find it difficult to generate and control the story elements as characters, setting, and the story line. Accordingly, it seems necessary to provide students with opportunities to express their abilities in writing stories.

Pictorial stories help students develop their sense of story, demonstrate an understanding of sequence, practice oral or written story telling skills and expand their cognitive abilities. Al-Shra'ah (2010) mentioned that one important way of getting students interested in learning English is through the use of various audio visual aids. Khwaileh (1991) emphasized the importance of using pictures in teaching English. He found that students who used the pictures as an aid for writing wrote more and better than students who used the group discussion or the traditional method.

Pictures are considered important visual aids for learning and teaching English in Action Pack textbooks. The General Guidelines and General and Specific Outcomes for the English Language for the Basic and 
Secondary Stage (2006) stresses that attention should be drawn to the effective methods of using textbook pictorial representation to help teach English as a foreign language and to reinforce positive thinking about Jordan and the world among the students.

\section{Problem and Significance of the Study}

Throughout the researcher's experience as a teacher and a supervisor of English in the Ministry of Education for more than 12 years, she has noticed that students are weak in the writing skill; they are not motivated to write. Many other colleagues and parents have also expressed their dissatisfaction with this weakness.

Many Jordanian researchers found that most students in Jordan are unable to write properly (Ababneh, 1996; Abed, 1990; Al-Hasan, 2006; Batayneh, 1986; Magableh, 1997). They believe that the technique of teaching writing is one reason for students' weakness. Students' problems in writing range from the inability to produce a single meaningful sentence in some cases (Khwaileh, 1991) through the inability to establish compatibility between the deep structure and surface forms (Al-Quran, 2002) to the inability to "produce coherent somewhat correct passage" in most cases (El-Abed, 1992). These problems stand out in the General Secondary School Certificate Exam. Many students hand in the English language papers without bothering to answer the writing question and many of those who bother do not write: What they actually do is scribbling.

Most of the traditional techniques have not improved the students' abilities in writing. Therefore, the researcher adopts a technique based on pictorial stories that may enhance students' level in writing. This study is designed to investigate the direct effect of the pictorial story-based writing instruction on students' writing performance.

\section{Purpose and Question of the Study}

This study is designed to investigate the effect of a pictorial story-based instructional EFL writing program on enhancing the writing performance of Jordanian secondary students. This study attempts to answer the following question: Are there any significant differences in 11th grade students' mean scores on the English writing achievement test due to the instructional program, gender, the interaction between the instructional program and gender?

\section{Definition of Terms}

\section{Current Technique}

It refers to the ordinary technique in teaching writing which includes: the pre-writing stage in which students discuss the main ideas with the teacher, then the students write the first draft, finally students write their final draft and receive feedback from the teacher.

\section{Secondary Stage}

This stage is divided into two grades: the 11th grade and 12th grade.

\section{Wordless Picture Book}

It is a "pure picture book", telling entire stories through pictures combined with no texts or slight texts and offers surprising varieties in topics, themes, and levels of difficulty (Hillman, 1995; Jalongo, Dragich, Conrad, \& Zhang, 2002). 
It is "a unique art object, a combination of image and idea that allows the readers to come away with more than the sum of the parts" (Kiefer, 1995, p. 6). Wordless picture books in this study are defined as books that have no written text to accompany the pictures and they tell stories entirely through graphic illustrations.

\section{Pictorial Stories-Based Program}

It refers to the stories which are presented without words; their pictures present the main points in a narrative story through the use of illustrations. No written text is used to carry the story line. They convey meaning and transport the student through pictures arranged in sequence; the student must express his/her thought through writing.

\section{Fluency}

Huang (2009) defined fluency as the number of relevant responses. Fluency in this study is defined as a large number of ideas in a text.

\section{Flexibility}

Huang (2009) defined flexibility as the number of details used to extend a response, in this study it refers to the wide variety of ideas in a text.

\section{Originality}

Huang (2009) defined originality as the number of unusual and relevant responses determined by statistical infrequency, in this study it refers to unusual, statistically infrequent ideas.

\section{Limitations of the Study}

The generalization of the results of the study will be limited by the following factors:

(1) This study is limited to the 11th grade students in Mafraq First Directorate of Education.

(2) This study focuses on the teaching of English as a foreign language in Jordanian public schools. Therefore, the results may not apply to other contexts such as private schools.

(3) Writing short stories was limited to the stories that were based on given pictures arranged in sequence in order to present the main points in a narrative.

\section{Review of Related Literature}

Hijazi (1985) investigated the effect of using picture story in teaching English techniques at the preparatory stage. The study included 138 students. The results of the study indicated that the students in the experimental groups were able to produce more sentences describing the characters in the given pictures than the students in the experimental groups.

Khwaileh (1991) conducted a study in which he compared between students' achievement in writing quantitatively and qualitatively. The sample of the study consisted of 168 students. The sample was divided into three groups: the traditional (control), the oral discussion group, and the pictures groups (experimental groups). The three groups were asked to write a paragraph based on the type of activity assigned to them: traditional, oral discussion, and pictures. The findings of the study indicated that there were statistically significant differences between the students mean scores quantitatively and qualitatively for the experimental groups over the traditional one. 
Ellis (2003) studied story writing, planning, and creativity. The purpose was to explore the different demands of scripted and unscripted story writing task and the extent to which the task prompted pupils to adopt different writing behaviors and attitudes. The researcher investigated a sample of 253 stories produced by 145 Scottish children in four schools from different local authorities. The picture-sequence and modeled-story tasks provided ready-made decisions about the characters, events direction and the boundaries of the story. This study showed that creativity and imagination could be taught and developed. Unscripted stories produced the most complex story structures although the structural support provided by scripted story tasks produced more consistent results.

Henry (2003) investigated creative writing through wordless picture books. The purpose was to expose middle class students to wordless picture books and help them to develop lines orally and in writing. The sample included middle class students in Marco Polo Education Foundation in USA. During the four 45-minute lessons students explored various wordless picture books. They developed oral and written story lines for wordless picture books and they also developed critique story lines for peers. The researcher found that wordless picture books develop students' writing skills, as well as their creative writings.

Faoury (2007) investigated the effect of teaching CoRT Program 4 entitled "Creativity", that stands for Cognitive Research Trust, which is written by Edward Debono (2004). The researcher aimed at teaching creative and critical thinking, on the gifted learners' creative abilities in writing through wordless books. The sample of the study consisted of 36 gifted students in Ein El-Basha Center Gifted Students. A pretest measuring fluency, flexibility and originality was administered for both groups. While the CoRT program was demonstrated through 20 sessions taught for a period of three months for the experimental group, the control group continued studying in the traditional way. The study showed that the mean score of the experimental group was significantly higher than the mean score of the control group on fluency, flexibility and originality which indicates that the CoRT Program No. 4 entitled "Creativity" developed the gifted learners' creative abilities in writing English short stories.

Although the genre of wordless picture books has been expanded for more than 20 years, their successful use is continually being revisited, revived, and revised by teachers and the other scholars (Cassady, 1998; Murphy, 2002). A number of research studies have shown that using wordless picture book is an effective worthwhile tool for developing reading, writing, and speaking of all students who have been provided the appropriate guidance and encouragement (Cassady, 1998; Crawford \& Hade, 2000; Murphy, 2002). Cassady convincingly argues that "wordless picture books guarantee successful reading experiences simply because they contain no "right' words" (p. 429); therefore, students tend to respond well to reading when their reading barriers are broken down. Teachers may find that wordless picture books are the perfect vehicle for students to construct meaning and create their own texts while they are reading.

Even though wordless picture stories are used mostly by children, it was found that wordless picture stories can be used with different learners of different ages and levels of different English language proficiency. Despite the great significant value of wordless picture stories, their real importance has not been recognized yet. So, the researcher hopes that the present study will be an asset to this situation in Jordan.

\section{Method and Procedures}

This section presents the methods and procedures that were used to conduct this study. It includes 
participants, instruments, procedures, statistical analysis, data collection, and data analysis techniques.

\section{Participants of the Study}

Two public schools in Mafraq Directorate of Education were chosen purposefully to form the participants of the study. The sample of the study consisted of four 11th grade scientific classroom sections (just two sections from each school) during the first semester of the academic year 2012-2013 as follows: (1) two male scientific sections $(n=82)$ and (2) two female scientific sections: $(n=86)$. Table 1 shows the distribution of the participants.

Table 1

Distribution of the Subjects by Gender and Type of Group

\begin{tabular}{lclr}
\hline Gender & Number of students & School & Total \\
\hline Male & 82 & Aydoun Secondary School for Boys & 82 \\
Female & 86 & Prince Raya Bent AL-Hussien Secondary School for Girls & 86 \\
Total & 168 & & 168 \\
\hline
\end{tabular}

\section{Instruments of the Study}

The researcher used the following instruments.

The story writing ability test. The researcher developed an instrument which she used as a pretest and a posttest. The pretest consisted of a wordless picture sheet in the form of a series of eight pictures arranged without any text in order to test students' originality, flexibility, and fluency in writing short stories. These pictures presented the main events of the story and conveyed meaning for the reader through pictures only. The topic of the series of pictures was about "Aliens" which were adopted from an article about story telling skills.

Test validity. A panel of jury (two teachers of English, two supervisors, two university EFL professors, one university measurement and evaluation professor, one university Islamic Studies professor, and one graphic designer) helped to validate the instrument of the study. They were asked to evaluate critically the pretest and the criteria of evaluating the students' writing of short stories and to respond with respect to: (1) appropriateness of the tested linguistic items, (2) suitability of the test wording, (3) suitability of criteria wording, (4) suitability of the criteria items to measure writing short stories, and (5) suitability of the pictures.

All the recommendations of the judges were taken into account during revising the criteria of evaluating the short stories and the pretest. Modifications like changing the pictures to suit social values and providing sources to the pictures was done according to their suggestions and recommendations.

Test reliability. The researcher applied a pilot study on 15 learners of the same grade in order to test the reliability of the pretest. The researcher applied the pretest to measure the students' ability in writing short stories and to find out the reliability of the pretest by applying Test-Retest reliability which provides an internal consistency measure for reliability.

The students in the pilot study were asked to generate stories for the wordless picture in 50 minutes.

Each story was evaluated by the two teachers and the researcher. The three evaluators were working independently. Reliability for the consistency of evaluators (the two teachers and the researcher) was also calculated in order to determine the reliability for the second instrument (evaluation scale). The evaluators' scores on fluency, flexibility, and originality were used to determine the reliability of the criteria of evaluating 
short stories. The overall reliability was 0.951 which means that the criteria of evaluating the learners' short stories were reliable.

The instructional program. The Pictorial Story-Based Instructional Program. The purpose of the Pictorial Story-Based Instructional Program is to design lesson plans that teach students the skills and strategies involved in writing short stories, this program aims at promoting the students' listening, speaking, reading, and writing skills in English by using wordless stories. The individual lesson plans include very specific objectives for each lesson. However, since this study focuses on students' short story writing, the specific objective of this program is that the students should be able to write well-developed short stories about 100 words at least (they were asked to generate their coherent events and several opening sentences to attract readers into their fictitious world and generate their own story elements in accordance with the following criteria: (1) with wide variety of sentence length; (2) broad command of new effective words and idioms; (3) many helpful details; (4) mastery of story elements; (5) well-observed mechanics of writing; (6) well organized and coherent writing; (7) correct tense and time sequence; (8) control of complex structure; (9) with few grammatical errors; (10) high realization of rhetorical devices as smile, metaphor, etc.; (11) many unusual/unpredictable events; (12) a distinguished and an unfamiliar title for the story; (13) clear story element; and (14) appropriate language use.

The components of the program include the following:

(1) A teacher's guide that includes the following: (a) an introduction that provides the teacher with information about pictorial story, descriptions of the aims, contents, components and methodology of the Pictorial Story-Based Instructional Program and procedures of presenting the activities; (b) 23 pictorial story lesson plans which are developed by the researcher. They include detailed notes on new ideas to use in relation to each of the original activities and how to use these new ideas; and (c) new students' worksheets.

(2) Handout of short stories, "WRITE RIGHT".

(3) A copy of "The Stages of Process Writing".

(4) A copy of the "Teaching Short Stories for teachers and students".

Instructional program validity. The program was evaluated by a panel of jury, comprising two teachers of English, two supervisors of English, two university EFL professors, one university Islamic Studies professor and graphic designer. The judges were also invited to include any comments and recommendations they saw as appropriate. All the recommendations of the judges were taken into account.

Teachers' training. The Pictorial Story-Based Instructional Program needs that teachers should make sure they understand the importance of the short story writing which is based on wordless pictures. Then, they should apply this program to themselves to determine their own story writing profiles; this provides them with the necessary experiential understanding of the program and enables them to personalize its content.

Therefore, this training is an attempt to develop teachers in teaching writing stories through pictures and provide them with sufficient knowledge that enables them to implement the program effectively in their classes which consequently may develop students' writing skills.

This training was carried out for four days by the researcher.

Students' training. Recent research supported the notion that learners benefit from instructional approaches that help them reflect upon their own learning processes. Therefore, it is essential to teach students about short 
stories. The most direct way to introduce the program to students is simply to explain it to them. Therefore, teachers were expected allocate one lesson time for explaining the importance of short story writing to their students.

\section{Procedures of the Study}

The study was conducted at the beginning of the first semester of the academic year 2012/2013, and it lasted for 12 weeks. In the summer of 2011/2012, the principals of the two selected schools were contacted and two meetings, one with each principal, were arranged. In the meetings, the purpose and the procedures of the study as well as the program were explained to each principal.

Early first semester (2012/2013), four initial meetings were held with the teachers, which aimed at informing and training them on the study purpose and procedures. There was also a discussion of the program and the way of implementing it in their classrooms. Each teacher was provided with reading materials.

During the first semester, the Story Writing Test was developed and validated, and its reliability was ensured. The Pictorial Story-Based Instructional Program was also developed and validated. Furthermore, the teachers were exposed to a variety of training activities that included the following:

(1) Each teacher had experiential knowledge of the program by training them for four days.

(2) They were involved in evaluating both the test and the teaching program.

(3) Each teacher observed demonstrations by the researcher of some new activities. The demonstrations were done with students who were not involved in the experiment.

A permission to conduct the study in the selected schools was obtained from the Ministry of Education. During the time of the experiment, several visits (at least two visits a week) were made to each school. During these visits the following activities took place:

(1) At times, there was some sort of clinical supervision that included a pre-conference, an observation, and a post-conference.

(2) At other times, the visits were limited getting feedback from teachers, principals and students about different aspects of the experiment such as difficulties, reactions, and the amount of the covered of the materials.

(3) Yet other visits aimed at viewing and/or listening to some students' work which was related to the activities of the experiment.

At the end of the experiment, the post-test was administered for all students in the control and experimental groups. Papers were scored, and scores were analyzed.

\section{Study Design}

The statistical design adopted is a quasi-experiment designed involving a pretest and posttest. The researcher designs the Pictorial Story-Based Instructional Program that contains aims, contents, components, and methodology.

\section{Variables of the Study}

This study had of the following variables:

(1) The independent variable of this study is the instructional program (The Pictorial Story-Based Instructional Program).

(2) The dependent variable is students' scores on the story writing ability test. 


\section{Data Collection}

The data for this study were collected from four schools, two for boys and two for girls in Mafraq Directorate of Education. The experiment started on the first of September 2012. The experiment lasted for 12 weeks. Moreover, the researcher observed the whole experiment to guarantee the right implementation of the Pictorial Story-Based Instructional Program.

\section{Data Analysis}

In analyzing data of this study, the following statistical techniques were used:

(1) Means and standard deviations were computed to compare means for the control and experimental groups on the posttest.

(2) Data of the pre-test and post-test were calculated for statistical analysis (SPSS). Means and standard deviations for the students' overall achievement scores were calculated.

(3) A two-way (ANOVA) was used in order to answer the study question.

(4) A two-way (ANCOVA) was used to find whether there are statistical differences in the means of method, gender, and interaction between them.

\section{Results of the Study}

This section presents the results of the study concerning the effect of a pictorial story-based instructional EFL writing program on enhancing the writing performance of Jordanian secondary students.

To answer the following question: "Are there any significant differences in 11th grade students' mean scores on the English writing achievement test due to the instructional program, gender, the interaction between the instructional program and gender?", mean scores and standard deviations and estimated marginal means for all students achievement on the pretest and posttest were calculated as shown in Table 2 below.

Table 2

Mean Scores and Standard Deviations and Estimated Marginal Means for Students’ Achievement According to Group and Gender Variables

\begin{tabular}{|c|c|c|c|c|c|c|c|}
\hline \multirow{2}{*}{ Group } & \multirow{2}{*}{ Gender } & \multicolumn{2}{|c|}{ Pre } & \multicolumn{2}{|c|}{ Post } & \multirow{2}{*}{-Estimated marginal means } & \multirow{2}{*}{$\mathrm{N}$} \\
\hline & & Mean & Std. deviation & Mean & Std. deviation & & \\
\hline \multirow[t]{3}{*}{ Experimental } & Male & 4.93 & 2.184 & 7.22 & 1.878 & 7.43 & 41 \\
\hline & Female & 4.95 & 2.171 & 7.14 & 1.934 & 7.33 & 43 \\
\hline & Total & 4.94 & 2.164 & 7.18 & 1.896 & 7.38 & 84 \\
\hline \multirow[t]{3}{*}{ Control } & Male & 5.15 & 2.297 & 5.54 & 2.169 & 5.57 & 41 \\
\hline & Female & 5.70 & 2.110 & 6.02 & 2.155 & 5.60 & 43 \\
\hline & Total & 5.43 & 2.208 & 5.79 & 2.163 & 5.58 & 84 \\
\hline \multirow[t]{3}{*}{ Total } & Male & 5.04 & 2.230 & 6.38 & 2.187 & 6.50 & 82 \\
\hline & Female & 5.33 & 2.161 & 6.58 & 2.111 & 6.47 & 86 \\
\hline & Total & 5.18 & 2.193 & 6.48 & 2.144 & 6.48 & 168 \\
\hline
\end{tabular}

Table 2 shows that there is a slight variance in the means (0.24) of the pretest according to Group and Gender; to find out whether there are statistical significant differences among these means, two-way ANOVA was conducted and the results are shown in Table 3. 
Table 3

Results of the Two-Way ANOVA Related to Group, Gender, and Interaction Between Group and Gender Variables on the Pretest

\begin{tabular}{lcrlrl}
\hline Source & Sum of squares & \multicolumn{1}{c}{$d f$} & Mean square & \multicolumn{1}{l}{ S } & Sig. \\
\hline Group & 9.746 & 1 & 9.746 & 2.031 & .156 \\
Gender & 3.506 & 1 & 3.506 & .731 & .394 \\
Group * Gender & 2.889 & 1 & 2.889 & .602 & .439 \\
Error & 786.879 & 164 & 4.798 & & \\
Corrected total & 803.280 & 167 & & & \\
\hline
\end{tabular}

Table 3 shows that there are no statistically significant differences at $(\alpha=0.05)$ in the pretest due to group, gender, and the interaction between group and gender variables. This shows that those groups were equal according to group, gender, and interaction between them.

Table 2 shows that there is an apparent difference of 1.39 on the posttest grades between the mean scores of the experimental group and the control group in favor of the experimental group. To find out whether there are statistical significant differences between these means, two-way ANCOVA was conducted and the results are shown in Table 4.

Table 4

Results of the Two-Way ANCOVA Related to Group, Gender, and Interaction Between Group and Gender Variables on the Posttest

\begin{tabular}{lcccrc}
\hline Source & Type III sum of squares & $d f$ & Mean square & \multicolumn{1}{l}{ F } & Sig. \\
\hline PRE (covariate) & 533.666 & 1 & 533.666 & 588.974 & .000 \\
Group & 133.805 & 1 & 133.805 & 147.673 & .000 \\
Gender & .050 & 1 & .050 & .055 & .814 \\
Group * Gender & .189 & 1 & .189 & .209 & .648 \\
Error & 147.693 & 163 & .906 & & \\
Corrected total & 767.946 & 167 & & & \\
\hline
\end{tabular}

Table 4 reveals that the $F$ value of 147.673 for the group was statistically significant at $(\alpha=0.05)$. This means that the improvement in the performance of the experimental group students on the short story writing test was due to the treatment which adopted the Pictorial Story-Based Instructional Program.

It is also indicated in Table 4 that $F$ value of the 0.209 for the group/gender interaction was not statistically significant at $(\alpha=0.05)$.

\section{Discussion, Conclusion, and Recommendations}

This study was an attempt to investigate the effect of a pictorial story-based instructional EFL writing program on enhancing the writing performance of Jordanian secondary students.

\section{Discussion of the Results Related to the Question of the Study}

The results show that the experimental group students who were taught through the Pictorial Story-Based Instructional Program significantly outperformed the control group students who were taught in the conventional teaching program.

An interpretation of this result is that the Pictorial Story-Based Instructional Program developed students' 
fluency, flexibility, and originality in writing short stories. Students were able to produce large numbers of ideas. This indicated that the program developed the students' ability to expand, support, and elaborate on their ideas by giving many helpful details. Many students were able to personalize their stories by giving names to the characters and places. Students showed better command of new effective words and idioms. That is to say the students applied what they learned in the lessons in their own writing.

Students seem to have developed better control of story elements and better ability of producing logically cohesive and organized sentences.

Students showed better flexibility by producing a wide variety of ideas. Students moved between familiar and imaginative ideas easily.

Students were able to produce unusual and frequent ideas. Students were more able to build their writing skills to ultimately produce original stories; they were more able to build unpredictable events and infrequent ideas. They avoided clichés and predictable events by using ambiguity, gaps, and openness.

The results show that there are no significant differences at $(\alpha=0.05)$ in 11th grade students' mean scores on the English writing achievement test due to the gender and interaction between the instructional program and gender. This indicates that program/gender interaction has no significant effects on students' writing ability. This means that only the Pictorial Story-Based Instructional Program was behind the experimental group significant improvement in the writing ability and that gender differences had no significant contribution to this result.

The students showed a marked improvement in their writing skills. The results of this study show that the students improved their sequencing skills by retelling the story in chronological order with details and consistent use of time-order words. The benefits of using pictorial stories show that students can improve their visual literacy and oral to written expression, promote their writing and thinking skills, and enhance their enjoyment of the writing process.

The students learned how to write in the method of process writing.

\section{Conclusion}

It was found that using this program has an effective role in developing learners' story writing which can be stimulated after studying the program lessons. Moreover, students had positive attitudes toward using such program.

It can be said that writing short story can be taught using an appropriate program; it is the outcome of appropriate practice using appropriate programs in order to stimulate the learners' ability to produce original and creative products. It can be claimed that the pictorial-based program is an appropriate program which can stimulate the learners' imagination and provide them with the suitable environment to develop their fluency, flexibility, and originality while writing stories.

This experimentation with the pictorial-based program encourages the hope that the method is vital and flexible enough for use in standard classrooms. The use of the program holds promise as viable ingredient in English as a second language (ESL) classes. Moreover, untraditional programs can stimulate the students' creativity based on appropriate programs and qualified teachers.

\section{Recommendations of the Study}

Based on the findings of this study, it may be fruitful to outline some recommendations which aim at 
developing the students' writing.

For teachers. (1) Vocabulary being the building blocks on which language stands, teachers need to focus on developing this area among the learners by making it an active learning component.

(2) It is a proven fact that learners achieve optimum learning when specific need related media are applied in the teaching process. As a corollary to this, various audio visual aids should be incorporated into the teaching process which will also enhance tertiary skills like computer usage among the learners.

(3) Learning divorced from practicum is frowned upon by educationists today. Curriculum as well as pedagogy must be in keeping with the times: They should be culturally and globally relevant.

(4) Co-operative learning is a successful means to foster the individual and the group's learning. Pair or group learning should be actively encouraged in environments where learning output is otherwise warped or poor.

(5) This study encourages teachers working with students to use wordless picture books to develop students' writing skills. By doing so, both students and teachers will be challenged to move toward new and exciting levels of accomplishment. Therefore, teachers may wish to consider making room for reading and discussing wordless picture books within the curriculum.

For supervisors of the Ministry of Education. Supervisors should hold more writing workshops to discuss possible ways of improving students' writing.

For researchers. (1) Researchers should conduct similar studies to find out the effect of this program on other variables.

(2) Researchers should conduct similar studies at the university level.

(3) Researchers should conduct similar studies for the basic stage students.

For text-books designers. Text-books designers should design syllabuses for writing that focus on wordless picture books in language writing.

\section{References}

Ababneh, S. (1996). Problems facing EFL Jordanian students in expository writing in Arabic and English (Unpublished master's thesis). Yarmouk University, Irbid, Jordan.

Abed, R. F. (1990). The effect of feedback on the writing performance of community college English language majors (Unpublished doctoral dissertation). The University of Jordan, Amman, Jordan.

AI-Hishoush, M. A. (2006). A context analysis of two national and international textbooks in Jordan based on aspects in teaching English (Unpublished master's thesis). Amman Arab University for Graduate Studies, Amman, Jordan.

Al-Abed Al-Haq, F., \& Al-Sobh, M. (2012). Online linguistic messages of the Jordanian secondary students and their opinions toward a web-based writing instructional EFL program. International Journal of Humanities and Social Science, 2(6), 228-299.

Al-Bataineh, A. (2010). The effect of the internet on improving foreign language students' writing performance. An-Najah Univ. J. of Res. (Humanities), 24(4), 1243-1255.

Al-Hasan, S. M. (2006). The effect of a proposed conference based programme on developing writing and critical thinking skills of upper basic stage EFL students in Jordan (Unpublished dissertation). Amman Arab University for Graduate Studies, Amman, Jordan.

Al-khresheh, M. (2010). Interlingual interference in the English language word order structure of Jordanian EFL learners. European Journal of Social Sciences, 16(1), 103-113.

Al-Quran, M. (2002). The class-function confusion in the complex sentence structure: A study of EFL student composition errors. DIRASAT: Human and Social Science, 20(3), 821-835. 
Al-Shra'ah, M. (2010). An analysis of pictures in action pack textbook series (Unpublished master's thesis). Yarmouk University, Irbid, Jordan.

Batayneh, M. (1986). Contrastive text linguistic and discourse analysis insights into teaching writing at advanced level with special referable to the Jordanian context (Unpublished master's thesis). University of Salford, Manchester, UK.

Bear, J. (1988). Let's not handicap able thinkers. Educational Leadership, 45(7), 66-71.

Bland, C., \& Koppel, L. (1988). Writing as a thinking tool. Educational Leadership, 45(7), 58-60.

Brown, H. D. (1987). Principles of language learning and teaching. Englewood Cliffs, NJ: Prentice Hall.

Calkins, L. (1994). The art of teaching writing (2nd ed.). Portsmouth, NH: Heinemann.

Carter, P. A., Holland, S. M., Mladic, S. L., Sarbiewski, G. M., \& Sebastian, D. M. (1998). Improving students writing skills using wordless picture books (Unpublished master's abstracts international). Saint Xavier University and IRI Sky Light, Chicago.

Cassady, J. K. (1998). Wordless books: No-Risk tools for inclusive middle grade classrooms. Journal of Adolescent and Adult Literacy, 41(6), 428-432.

Conley, M. (1995). Content reading instruction: A communicative approach (2nd ed.). New York: Mc Graw-Hill, Inc..

Cotton, K. (1997). Teaching thinking skills, school improvement research series (SIRS). Retrieved from http:// www. nwrel. on! scpd $\backslash \operatorname{Sirs} \backslash 6 \backslash$ cul1. htm

Crawford, P. A., \& Hade, D. D. (2000). Inside the picture, outside the frame: Semiotics and the reading of wordless picture book. Journal of Research in Childhood Education, 15(1), 66-80.

El-Abed, W. (1992). The effect of selected prewriting activities on the quantity and quality of first year students' composition in vocational training centers (Unpublished master's thesis). Yarmouk University, Irbid, Jordan.

Ellis, S. (2003). Story-Writing planning and creativity reading. Literacy and Language, 37(1), 27-31.

El-Mustafa, A. (1988). An evaluation of the TEFL text book (PETRA) for the first preparatory class in Jordan (Unpublished master's thesis). Yarmouk University, Irbid, Jordan.

Faoury, O. (2007). The effect of teaching CORT program No. (4) entitled "Creativity" on the gifted learners' writings in Ein El-Basha Center for gifted students (Unpublished master's thesis). University of Jordan, Amman, Jordan.

Garvie, E. (1990). Story as vehicle: Teaching English to young children. Clevedon: Multilingual LTD.

Grabe, W., \& Kaplan, R. (1996). Theory and practice of writing. London: Longman.

Hairston, M. (1982). The winds of change: Thomas Kuhn and the revolution in the teaching of writing. College Composition and Communication, 33(2), 76-88.

Henry, L. (2003). Creative writing through wordless picture books. Retrieved from Educational Resource Information Center (ERIC). (ED 477997).

Hijazi, M. S. (1985). An Investigation into the effect of using the picture story techniques in teaching English at the preparatory stage (Unpublished master's thesis). The University of Jordan, Amman, Jordan.

Hillman, J. (1995). Discovering children's literature. Englewood Cliffs, NJ: Prentice Hall.

Howe, K. (1996). Traditional story: Intergenerational ties of past to present. The National Conference for Creating the Quality School, Oklahoma City, Japan.

Huang, C. P. (2009). Writing wordless picture books to facilitate English writing. Asian EFL Journal, 38(6), 45-57.

Jalongo, M., Dragich, D., Conrad, N., \& Zhang, A. (2002). Using wordless picture books to support emergent literacy. Early Childhood Education Journal, 29(3), 167-177.

Karsou, M. (2005). An evaluation of action pack textbooks as perceived by language supervisors, teachers and students (Unpublished master's thesis). The University of Jordan, Amman, Jordan.

Khwaileh, F. (1991). A comparative study of the effects of some selected prewriting activities on the quantity and quality of paragraphs written by ninth grade students in Ramtha (Unpublished master's thesis). Yarmouk University, Irbid, Jordan.

Kiefer, B. Z. (1995). The potential of picture books: From visual literacy to aesthetic understanding. Englewood Cliffs, NJ: Prentice-Hall.

Magableh, A. F. (1997). An investigation of the instructional context of writing development in Jordanian primary schools (Unpublished dissertation). University of Bristol, Bristol, England.

Morgan, S. M., \& Foster, J. (1999). Creativity in the classroom. Gifted education international, 14(1), 29-43.

Murphy, P. E. (2002). Why use picture books in the middle school curriculum?. Tennessee Reading Teacher, 31(1), 15-19.

Newton, P. (2000). Teaching for understanding: What it is and how to do it (1st ed.). London: Routledge Falmer.

Oslon, C. B. (1984). Fostering critical thinking skills through writing. Educational Leadership, 42(3), 28-39.

Presseisen, B. Z. (1988). Avoiding battle at curriculum gulch: Teaching thinking and content. Educational Leadership, 45(7), 7-8. 
Saleh, N. M. (1990). An evaluation of the TEFL text book (PETRA) for the second preparatory class in Jordan (Unpublished master's thesis). Yarmouk University, Irbid, Jordan.

Schneider, D. (2006). Class novels and creative writing. Retrieved from American Library Association\Book Link, 45-46. (ED 203093191).

Toubat, M. (2003). The effect of a discoursal technique on the writing skills of the Jordanian academic eleventh graders (Unpublished dissertation). Amman Arab University, Amman, Jordan. 